\title{
Corporate Board Attributes and Dividend Payout Likelihood
}

\author{
Idris Adamu Adamu ${ }^{1,2, *}$, Rokiah Ishak ${ }^{1}$ and Nor Laili Hassan ${ }^{1}$ \\ ${ }^{1}$ Tunku Puteri Intan Safinaz, School of Accountancy (TISSA-UUM), College of Business, Universiti Utara, \\ Malaysia \\ ${ }^{2}$ Department of Accounting, Faculty of Management Sciences, Federal University Dutsin-ma, Nigeria
}

\begin{abstract}
Extant literature has shown that corporate governance influences dividends policy. However, the effect of diversity on the likelihood to distribute cash dividends is scarce in the literature. Therefore, this study is aimed at exploring the influence of gender diversity and financial expertise on the likelihood of dividends payout. Pooled logistic regression was used on a sample of data from non-financial listed firms in Nigeria spanning from 2009 to 2015. The study documents gender diversity and financial experts have significant effect on a firm's likelihood to distribute cash dividends. The results remain unchanged after adjusting the standard errors for clustering at a firm. The overall finding suggests that diversity in terms of gender and expertise play a critical role all things being equal in determining the decision to pay cash dividends shareholders of listed firms in Nigeria.
\end{abstract}

Keywords: Likely to pay dividends, gender diversity, financial expertise, corporate attributes.

\section{INTRODUCTION}

Dividend policy has been an issue in the Nigerian market. Nwidobie (2011) noted that $85 \%$ of the shareholders in the market are not satisfied with the dividend policy of the listed firms. According to Proshare (2013) as cited by Abdulkadir, Abdullah, and Wong (2016), that 43 of 200 firms persistently in failing to pay dividends between 2009 and 2013. The study further revealed that dividend payout has declined over the years. Hence, agency related problems may emerge in the firms.

Board attributes are one of the internal mechanisms used to address the agency problem (Brown, Beekes, \& Verhoeven, 2011; Man, Kong, \& Wong, 2013). The board of directors are the top most body that regulates the affairs of corporate entities and act on behalf of the shareholders. The board as a representative of the owners is expected to play a major role in addressing agency conflicts (Jensen \& Meckling, 1976). However, this role may not subsist when the board members lack monitoring ability. Hence, the need for resource dependence theory in explaining the board's monitoring role becomes necessary (Hillman \& Dalziel, 2003). The resource dependence theory suggests that a director is a resource provider to the firm given his/her experience, skills and diversity (Arnegger, Hofmann, Pull, \& Vetter, 2013; Ooi, Hooy, \& Mat Som, 2015).

The board members are elected by the shareholders and are expected to play their role

*Address correspondence to this author at the Department of Accounting, Faculty of Management Sciences, Federal University Dutsin-ma, Nigeria; E-mail: adamuidris48@gmail.com effectively and efficiently. Specifically, members of the board are expected to have diversity in terms of gender, experience and cultural background that may bring greater and positive changes in the affairs of the corporate body (Mishra \& Jhunjhunwala, 2013). Besides social justice motives that call for equal opportunity for males and females in society and board in particular (Ali, Ng, \& Kulik, 2014), females tend to have different perspective in addressing issues. The perspective of a female may provide better opportunity to the firm for addressing its issues such as dividends in its existing environment. Thus, it is not surprising that code of corporate governance (CG) of 2011 of the Securities and Exchange Commission of Nigeria (SEC) has recommended gender diversity (Mordi \& Obanya, 2014) as well as financial experts at board and committee levels (Kibiya, Che-Ahmad, \& Amran, 2016).

The association of CG and dividends in mitigating agency conflicts within the firm could be derived from the hypothesis of La Porta, Lopez-De-Silanes, Shleifer, and Vishny (2000). They argued that corporate governance and dividends tend to play either a complementary or a substitute role in eradicating agency problems. Therefore, the role of a female director serving on a corporate board could be explained by agency and status characteristics theories. The agency theory describes that the reputations of a director may induce him/her to monitor a firm's management. Whereas, the status characteristics theory posits that individuals of low status are expected to have increased levels of ability such that the high status of others may be perceived as being the same as theirs (Terjesen, Sealy, \& Singh, 2009). In this regard, a female director is likely to employ her utmost best efforts on the corporate boards 
such that they serve as a role model (Terjesen et al., 2009) and eliminate the perceptions of being a lowstatus individual on board. Additionally, a female on board may strive hard to discharge her responsibilities on the board such as protecting the interests of shareholders by influencing the decision to pay dividends. Therefore, the study expects that as the percentage of female directors on board increases, firms will tend to show a greater probability of paying dividends.

However, financial experts are of paramount importance to a firm. They contribute greatly to the policies relating to finance and investments. These experts help in assessing the financial wellbeing of a firm and advising a firm on financially related issues. Defond, Hann, Xuedong, and Engel (2005) showed that the appointment of a financial expert director resulted in a positive market reaction in favour of the firm. In support of the previous evidence, Jeanjean and Stolowy (2009) indicated that financial experts are associated with better governance, and, recently, Kibiya et al. (2016) revealed that financial experts are related to greater financial reporting quality because a board member with financial with better governance and enhances monitoring, Thus, this study posits that a growing number of financial experts on firms may influence likelihood of dividend payout.

Studies on the impact of gender diversity and financial expertise on the likelihood of dividends payments are scarce. Only a handful of studies have attempted to examine this relationship. For instance, Byoun, Chang, and Kim (2016) and Pucheta-Martínez and Bel-Oms (2016) reported a positive association between gender and a dividend decision. These studies have focused on whether a firm pays a dividend or otherwise. However, the current study considers firms that are expected to pay given their financial characteristics. Therefore, the current study intends to determine this association using Nigerian data. Based on 596 firm-year observations, the study reveals a positive association between gender diversity and financial expertise on board and the likelihood of a dividend payout.

The study contributes in the following ways: First, most previous studies have considered whether a firm pays dividends or not as a proxy for likelihood to pay dividends. However, this study uses Fama and French (2001) methodology to model the likelihood of dividend payout. Second, previous studies have focused more on outside directors (Hu \& Kumar, 2004; Sharma,
2011) or firm characteristics (Abdulkadir et al., 2016) however, this study examines characteristics of the directors including gender and expertise who serve on the board.

Third, this study uses individual variables as opposed to a corporate governance (CG) index. Previous studies have examined (CG) using an index. Benjamin and Zain (2015) argued that the CG index has limitations on the outcomes because the components (for example board of directors, antitakeover laws, and ownership) of the index are grouped together to make up one item. The results from the grouping may be biased and inappropriate as each of the CG variables may have distinct characteristics as they relate to the likelihood to pay dividends. Therefore, the individual resultant effect may be reduced. Consequently, the current study is carried out in Nigeria where the market is at early stage of development compared to other markets within the Common Wealth Nations such as South Africa, Malaysia, Singapore and Australia among others.

Finally, this study differs from the evidence documented by Officer (2006) and (Tangjitprom, 2013). This study identifies firms that should pay dividends using firm size, return on assets and investment growth. Moreover, Officer's (2006) study considers a firm to be selected as a dividend payer, when it is predicted to pay dividends for two consecutive years. This selection process is too conservative and inflexible and, hence, underestimates the predicted payers. To avoid this bias towards the payers, this study based its selection to firms that are predicted to have dividends in the current year.

The rest of the paper is organized into the following sections. Section two articulates the literature review and hypothesis development on the association between board attributes and the likelihood to pay dividends. Section three provides the methodology and the sample description adopted for the study. Section four offers the empirical findings while the last section contains the conclusion.

\subsection{Corporate Governance in Nigeria}

Nigeria has embraced CG practices since 2003. In terms of investor protection, The World Bank (2017) has reported that of 190 economies ranked, Nigeria is ranked 33 in terms of investor protection as compared to Malaysia at 3, South Africa at 22 and Pakistan at 27. The development of CG in Nigeria, however, is characterized by founding families who in most times 
have full control of the boards along with the management (Adegbite, 2015). The families tend to be responsible for the strategic decisions and performance outcomes of listed companies. Notwithstanding, the aim of the CG is to bring about corporate accountability and the protection of the minority shareholders.

Corporate accountability became more pronounced after the structural adjustment program (SAP) of the 1990s, which was aimed at restructuring the entire economy. The post-SAP period witnessed the growth of private corporations in various sectors of the economy (Adewale, 2013). Therefore, accountability is expected to extend to minority investors whose rights will be protected from expropriation. This is because the existing corporate laws in the country emanated from Britain, which is a common law country, and thus are expected to be stronger in terms of investors protection (La Porta, Lopez-De-Silanes, et al., 2000) but subject to the enforcement of the laws (La Porta, Lopez-de-Silanes, Shleifer, \& Vishny, 2000).

The presence of corporate laws such as the Companies and Allied Matters Act 1999 (CAMA) in reality have does little to strengthen the practice of $C G$ in the country because the abuse of corporate power has come to the forefront (Adeyemi, 2010). Similarly, Adegbite (2015) also documented that Nigeria has weak institutional settings such the enforcement of corporate laws, and the self-regulatory initiatives of firms are likely to remain unattainable. In this regard, it might be difficult, if not impossible, for shareholders who wish to take legal remedy to do so. Moreover, Adegbite, Amaeshi, and Amao (2012) suggested that mechanisms such as corporate takeovers and shareholder activism in the country that may place pressure on non-performing firms or managers are either absent, weak or corrupt. Therefore, agency conflicts may likely prevail because some of the important mechanisms that may mitigate conflicts between managers and shareholders remain lacking. Hence, dividend payout may be used as a means of protecting shareholders. Therefore, conducting this study in Nigeria may provide incremental knowledge on the association between board attributes and likelihood to pay dividends.

\section{LITERATURE REVIEW AND HYPOTHESIS DEVELOPMENT}

\subsection{Gender Diversity and Likelihood to Pay Dividends}

Previous studies have indicated the importance of gender diversity (females on the board) and the role that they play on corporate boards. Adams and Ferreira (2009) noted that gender diversity immensely contributes to board decisions and contribute greatly to the firm. For example, female directors tend to reduce the amount of audit fees paid by firms as they provide greater monitoring services to the firm (Ittonen, Miettinen, \& Vähämaa, 2010). A female director is also associated with higher firm performance (Carter, D'Souza, Simkins, \& Simpson, 2010), a reduction in tax evasion (Kastlunger, Dressler, Kirchler, Mittone, \& Voracek, 2010), and also influences dividends decisions (Pucheta-Martínez \& Bel-Oms, 2016). This evidence provides indications that female directors credible and have value to the board and to the firm in general.

Likewise, gender diversity has been linked to theories such as the agency theory (Pucheta-Martínez \& Bel-Oms, 2016) and the status characteristic theory (Larkin, Bernardi, \& Bosco, 2013; Terjesen et al., 2009). Based on these theories, this study expects a positive relationship between gender diversity and the likelihood to pay dividends. Narrowing down the focus of this study, Pucheta-Martínez and Bel-Oms (2016) have documented a positive association between females serving on the board and the decision to pay dividends. This suggests that a female director puts more efforts along with her expertise to align the interests of the managers with those of the shareholders. Similarly, Byoun, Chang. and Kim (2016) from their comparative studies on gender and its effects on dividend, have revealed that gender diverse boards tend to pay higher dividends than non-gender diverse boards. Thus, this study proposed that:

$\mathbf{H}_{1}$ : Gender diversity is positively and significantly associated with the likelihood to pay dividends.

\subsection{Financial Experts and the Likelihood to Pay Dividends}

A heterogeneous board is said to be a board comprising members who differ in terms of demography and cognitive characteristics such as education, gender, expertise, nationality, age among others (Mishra \& Jhunjhunwala, 2013). A heterogeneous board is expected to bring about improvements in a variety of firm outcomes. According to Jensen (1993) shareholders are the prime beneficiaries from the services offered by a heterogeneous board of directors. monitoring to an advisory role resolving problem faced an advisory resolving problem faced by firms and corporate 
strategy development. Financial experts, in particular, are required by firms for corporate planning and determining issues that are likely to influence corporate value (Jensen, 1993). Agency theory emphasizes the importance of the financial expertise of an outside director based on the grounds that they are likely to monitor opportunistic managers and, hence, reduce agency-related costs (Jensen \& Meckling, 1976). Conversely, the resource dependence view of point considers the ability of directors as a condition providing the required monitoring services (Hillman \& Dalziel, 2003). A financial expert director (insider or outsider) may have the incentive to protect his/her reputation and will, therefore, provide services that will protect the interests of shareholders. Empirically, having financially expert directors both on board and at committee level is linked to the reduction of earnings management (Cunningham, 2008) and improving the quality of a firm's earnings (Kibiya et al., 2016). A financial expert creates value for shareholders in particular when they are representing financial institutions on boards (Güner, Malmendier, \& Tate, 2008) and leads to fewer earnings restatements (Agrawal \& Chadha, 2005). Positive stock market reactions normally follow the appointment of financial experts to the audit committee (Defond et al., 2005). Jeanjean and Stolowy (2009) concluded that financial expert directors play three major roles, which are: 1) corporate monitoring, 2) providing advisory services to CEOs and 3) paving the way to access access and secure financial resources, which, in turn, will improve corporate performance. From the perspective of payout policies, Custodio and Metzger (2014) reported that a company with a CEO who is a financial expert tends to pay more dividends. Therefore, financial experts may also enhance the decision to pay dividend by firms because they improve monitoring and the alignment with the interests of shareholders. In this sense, the study hypothesizes that:

$\mathbf{H}_{2}$ : There is significant and positive association between financial expertise on board and the likelihood to pay dividends.

\section{METHODOLOGY}

The study uses pooled logistic regression on a sample data over a period of seven years from 2009 to 2015. The study period is an important as it marked the period when the draft of 2011 SEC CG best practices was given to the public for their comments (Ofo, 2011) and its full implementation, which began in early 2011. The sample comprises approximately 596 firm year- observations, which are from non-financial listed firms on the main market of the Nigerian Stock Exchange. Listed financial firms were excluded because of their uniqueness (Baker, Dutta, \& Saadi, 2008; SetiaAtmaja, 2009) and because they have a specialized code issued by the Central Bank of Nigeria in addition to prudential guidelines that govern the operations of all financial firms.

\subsection{Variable Definitions and Measurement}

To examine the effect of board attributes on the likelihood to pay dividends, the study constructed the dependent variable likelihood of dividends payments (LKPD) using the following steps. First, the study identifies three firm characteristics that were previously used in the literature of propensity to pay dividends (Fama \& French, 2001; Fatemi \& Bildik, 2012; Ferris, Sen, \& Yui, 2006). These characteristics include return on assets, firm size, growth opportunities. Return on assets is measured using profit before interest and tax scaled by total assets, firm size is obtained by taking the logarithm of total assets, and investment growth opportunities are measured by market value of total capital to the book value of total assets. Market value of total capital is determined as book value of total assets less book value of equity plus market value of equity.

Second, annual logistic regressions were run over the sample period (7 years). The dependent variable is 1 , if a firm pays dividend in a year and 0 if otherwise. The explanatory variables are return on assets, firm size, and growth opportunities. The coefficients were then averaged based on the sampling period (7 years).

Third, to identify a payer, the values of the firm characteristics for each year were fitted into model (1) with average beta coefficients.

Fourth, following (Hu \& Kumar, 2004; Officer, 2006), a probability score was obtained for every firm in each year. Further and consistent with Officer (2006) , a firm is predicted to be a dividend payer when its predicted probability score is at least $50 \%$ and actually pays a dividend in that year is coded as 1 and 0 if otherwise.

$Y=\beta_{0}+\beta_{1} R O A+\beta_{2}$ FSIZE $+\beta_{3} I N V S T+e$

Where $Y=$ an indicator variable "1"one if firm pays a dividend in year and " 0 " otherwise, ROA = Return on Assets; FSIZE =Firm size; INVST = Market to book value of equity; and $\mathrm{e}=$ error term. 


\subsection{Independent Variables}

The main independent variables used for this study are gender diversity and financial expertise. Gender diversity (BDIVER) is measured as the percentage of female directors to the number of directors sitting on the board of a company. This measurement is in line with previous studies (Florackis, Kanas, \& Kostakis, 2015; Pucheta-Martínez \& Bel-Oms, 2016). Financial experts (FINEXP) on board is the number of directors who have educational backgrounds in accounting or a related discipline (Jeanjean \& Stolowy, 2009; Knyazeva, Knyazeva, \& Masulis, 2013). This is scaled by the number of directors sitting on the board. In other words, financial experts on board (FINEXP) is measured as the ratio of financial experts to the board size.

The control variables employed in this study include firm age, which is the number of years since listing because older firms may tend to pay dividends more than younger ones (Sharma, 2011). Firm size is also use as a control variable because larger firms may have more advantages in terms of economy of scale over smaller firms, The study uses logarithms of total assets as a measure of firm size and is in agreement with previous study (see for isntance, Byoun et al., 2016; Fatemi \& Bildik, 2012; Sharma, 2011). Firm leverage is also used to control for the influence of debt since these firms (indebted firms) may be less likely to pay a dividend. Leverage is measured as total debts to total assets (Abdulkadir et al., 2016; Byoun et al., 2016). Retained earnings, which is accumulated earnings to total capital (Byoun et al., 2016) is also considered in this study as a control variable. Firms with more accumulated cash may tend to pay more dividends than others because they have few or no new projects or may have greater advantages than others because they can finance projects internally (DeAngelo, DeAngelo, \& Stulz, 2006). The study also employs sales growth as a proxy for investment growth opportunities (Amidu \& Abor, 2006; DeAngelo et al., 2006) because high growth firms may need more cash to finance new projects and, therefore, are less like to pay dividends (Abor \& Fiador, 2013). Finally, year is controlled because of variation over time and yearspecific events may influence the decision of a firms to pay. Similarly, industries are also controlled for because of variations over time to account for any probable industry effect (Jiraporn, Kim, \& Kim, 2011).

The study uses five models. Likelihood of dividends payment is constructed using Model (1). This is a departure from the traditional study of $C G$ and dividend policy. Model (2) is used to estimate the impact of board diversity and financial expertise on the likelihood of dividend payment. These two variables remain unexplored on the scope of likelihood to pay dividends in the Nigerian Market. In the third model, which is model (3), an additional five independent variables are used as control along with industry and year control. This will ensure the model is specified correctly, and it is re-estimated using robust standard error to account for potential threat of heteroscedasticity. Moreover, the study also checked for the robustness of the results using model (4) by replacing the dependent variable (binary number) with cash dividend payout to total assets (continuous variable). This will enable the study to ascertain whether these factors affect the amount of dividend. The models for the study are shown below;

LKPD $=\beta_{0}+\beta_{1}$ BDIVER $+\beta_{2}$ FINEXP $+e$

LKPD $=\beta_{0}+\beta_{1}$ BDIVER $+\beta_{2}$ FINEXP $+\beta_{3}$ FAGE + $\beta_{4}$ FSIZE $+\beta_{5}$ FLEV $+\beta_{6}$ RETE $+\beta_{7}$ SLGRWT $+\beta_{j}$ IND + $\beta_{k} F I R M+e$

DVTS $=\beta_{0}+\beta_{1}$ BDIVER $+\beta_{2}$ FINEXP $+\beta_{3}$ FAGE + $\beta_{4}$ FSIZE $+\beta_{5}$ FLEV $+\beta_{6}$ RETE $+\beta_{7}$ SLGRWT $+\beta$ JIND + $\beta \mathrm{kFIRM}+\mathrm{e}$

Where LKPD is Likelihood to pay dividends, DVTS is dividends scaled by total assets, BDIVER is gender diversity, FINEXP is financial experts on board, FAGE is firm age, FSIZE is firm size, FLEV is firm leverage, RETE is retained earnings to total capital, SLGRWT is sales growth, IND and FIRM is industry and firms dummies respectively.

\section{RESULTS AND FINDINGS}

Descriptive statistics are reported in Table 1. The table shows that on average about $51.7 \%$ of the sampled firms paid dividends during the period. Gender diversity, which represent the percentage of female directors on board, indicates that female directors on board accounted for only $8.9 \%$ on the average among the sampled firms. Furthermore, some firms in the sample had no female directors on boards while others had up to $40 \%$ of female directors on board. For the presence of financial experts on board, the average value was $44 \%$ with a minimum of $16.7 \%$. and a maximum of $100 \%$. These statistics shows that the sampled firms tended to have a significant percentage of financial experts on their boards.

Regarding the control variables, the average years of the firms since listing was 21 years, and the 
Table 1: Descriptive Statistics

\begin{tabular}{|c|c|c|c|c|c|}
\hline Variable & Obs. & Mean & Std. Dev. & Minimum & maximum \\
\hline LKPD & 596 & 0.516 & 0.500 & 0.000 & 1.000 \\
\hline BDIVER & 596 & 0.088 & 0.095 & 0.000 & 0.400 \\
\hline FINEXP & 596 & 0.439 & 0.156 & 0.167 & 1.000 \\
\hline FAGE & 596 & 21.305 & 12.859 & 1.000 & 44.000 \\
\hline FSIZE & 596 & 6.982 & 0.755 & 5.095 & 8.772 \\
\hline FLEV & 596 & 0.538 & 0.210 & 0.146 & 0.907 \\
\hline RETE & 596 & 0.557 & 0.195 & -0.049 & 0.955 \\
\hline SLGRWT & 596 & 0.125 & 0.309 & -0.884 & 0.880 \\
\hline
\end{tabular}

Where LKPD is Likelihood to pay dividends, BDIVER is gender diversity, FINEXP is financial experts on board, FAGE is firm age, FSIZE is firm size, FLEV is firm LEVERAGE, rete is retained earnings to total capital SLSGRWT is sales growth.

maximum years of the sampling firms being in the capital market was 44 years. As depicted in the table, the mean of the firm size, which was natural logarithm of total assets (in millions of Naira), was 6.9 with a minimum and maximum value of 5.0 and 8.7 respectively. The average value of leverage was $53.8 \%$ with a minimum score of $14.6 \%$ and maximum value of $90.7 \%$. Retained earnings of these firms could either be accumulated profits (positive values) or losses (negative values) over a period. On the average, the firms had a mean of $55.7 \%$ with a standard deviation of $19.5 \%$ for the mean. The minimum value was less than 1 signifying accumulated losses of $4.9 \%$. On the other hand, the maximum value of the retained earnings to total equity is $88 \%$. Finally, the sales growth of these firms has an average value of $12.5 \%$ and ranged from 88 to $88 \%$ for minimum and maximum respectively. These values indicate a downturn of sales revenue of some companies.

Table 2 reports the correlation between variables using a one-way Pearson correlation. The correlation shows both positive and negative associations. The highest correlation score from the correlation table was $56 \%$ between likelihood to pay dividends and firm size. Conversely, the lowest value was $0.3 \%$ between retained earnings and firm age. Additionally, the correlation matrix between explanatory variables confirmed the absence of a perfect relationship. The study also checked for multicollinearity using variance inflation factors (VIF). The result for the VIF provided evidence of the absence of multicollinearity because none of the variables had a value that was equal to or greater than the 10 threshold (Gujarati, 2004).

Moreover, a model specification test was also conducted using linktest in the study. This is important so that misleading inferences will be avoided. The result of the linktest shows that the hat square was statistically insignificant $(\beta=-0.023$; z-statistics -0.70 ; $p<0.485)$. The statistic for the test implies that the model is correctly specified. In addition to the model specification, goodness of fit was also examined using the Hosmer-Lemeshow test. The test result shows that

\section{Table 2: Correlation}

\begin{tabular}{|c|c|c|c|c|c|c|c|c|}
\hline Variables & 1 & 2 & 3 & 4 & 5 & 6 & 7 & 8 \\
\hline 1. LLKD & 1.000 & & & & & & & \\
\hline 2. BDIVER & $0.160^{* * *}$ & 1.000 & & & & & & \\
\hline 3. FINEXP & $0.179^{* * *}$ & $0.177^{* * *}$ & 1.000 & & & & & \\
\hline 4. FAGE & $0.148^{* * *}$ & $0.120^{\star *}$ & $0.090^{*}$ & 1.000 & & & & \\
\hline 5. FLEV & -0.015 & -0.063 & 0.023 & $0.187^{\star * *}$ & 1.000 & & & \\
\hline 6. FSIZE & $0.562^{\star \star *}$ & 0.049 & $0.108^{* *}$ & $0.092^{*}$ & $0.174^{\star \star *}$ & 1.000 & & \\
\hline 7. SLGRWT & $0.473^{\star * *}$ & $0.101^{*}$ & 0.079 & $0.140^{\star * *}$ & -0.075 & $0.190^{\star * \star}$ & 1.000 & \\
\hline 8. RETE & 0.066 & -0.005 & -0.036 & -0.003 & -0.076 & $0.147^{\star * \star}$ & 0.004 & 1.000 \\
\hline
\end{tabular}

${ }^{*} p<0.01,{ }^{* *} p<0.05,{ }^{* * *} p<0.001$. 
the Chi square value was 4.43 with a probability of 0.817 and a degree of freedom of 8 . This result also confirmed the fitness of the model because the probability was found to be insignificant (Tarling, 2009). Finally, the Wald and likelihood-ratio tests were also employed in this study. The results from the tests showed that the Wald test had a Chi-Square of 127.49 at the $1 \%$ level of significance. Likewise, the likelihoodratio test with 1 degrees of freedom revealed a ChiSquare value of 6.45 and was statistically significant at the $5 \%$ level $(p$-value $=0.0111)$. Therefore, either the Wald or likelihood-ratio test can be used in assessing the model fit. Although likelihood-ratio test has a technical advantage over Wald test because they do not differ much, either can be accepted (Cock, 2014). Hence, the hypothesis that all parameters are simultaneously equal to zero is rejected and the conclusion is that the coefficients in the model have influence on the predicted variable, which is likely to pay dividends.

\subsection{Logistic Regression Results}

Table 3 reveals the models used in the study. Model (1) to model (3) are the pooled logistic regression results. Model (4) is the robust logistic model while model (5) is the OLS regression. The Likelihood Ratio (LR) Chi square ranging from 29.93 to 465.43 are all statistically significant at $p<0.0000$. Likewise, the Pseudo R-square ranged from 0.03 to 0.564 for model 1 to 4 respectively. The results show that gender on the board accounts for the likelihood to pay dividends. Consistent with the prediction, the study documents a positive association between gender diversity and likelihood to pay dividends in all four models. The results also indicate that firms with a female director on board are more likely to reach the decision to pay

Table 3: Logit Regression Results of Likelihood to Pay Dividends

\begin{tabular}{|c|c|c|c|c|c|}
\hline Variables & Model (1) & Model (2) & Model (3) & Model (4) & Model (5) \\
\hline \multirow[t]{2}{*}{ BDIVER } & $0.0292^{\star \star *}$ & $0.0400^{* * *}$ & $0.0394^{\star *}$ & $0.0394^{*}$ & $0.000977^{\star \star *}$ \\
\hline & $(0.00916)$ & $(0.0137)$ & $(0.0158)$ & $(0.0219)$ & $(0.000259)$ \\
\hline \multirow[t]{2}{*}{ FINEXP } & $0.0197^{* * *}$ & $0.0198^{* * *}$ & $0.0203^{* *}$ & $0.0203^{*}$ & $0.000597^{\star * *}$ \\
\hline & $(0.00530)$ & $(0.00760)$ & $(0.00826)$ & $(0.0109)$ & $(0.000146)$ \\
\hline \multirow[t]{2}{*}{ FAGE } & & -0.00437 & 0.00764 & 0.00764 & $0.000443^{* *}$ \\
\hline & & $(0.0106)$ & $(0.0127)$ & $(0.0227)$ & $(0.000216)$ \\
\hline \multirow[t]{2}{*}{ FLEV } & & $-0.0200^{* * *}$ & $-0.0210^{* * *}$ & $-0.0210^{\star *}$ & $-7.19 e-05$ \\
\hline & & $(0.00668)$ & $(0.00745)$ & $(0.00826)$ & $(0.000121)$ \\
\hline \multirow[t]{2}{*}{ FSIZE } & & $3.357^{* * *}$ & $4.083^{* * *}$ & $4.083^{* * *}$ & $0.0140^{* * *}$ \\
\hline & & $(0.321)$ & $(0.415)$ & $(0.515)$ & $(0.00376)$ \\
\hline \multirow[t]{2}{*}{ SLGRWT } & & $0.0741^{* * *}$ & $0.0839^{* * *}$ & $0.0839^{* * *}$ & $0.000293^{\star * *}$ \\
\hline & & $(0.00819)$ & $(0.00976)$ & $(0.0114)$ & $(8.14 \mathrm{e}-05)$ \\
\hline \multirow[t]{2}{*}{ RETE } & & -0.00206 & -0.00754 & -0.00754 & $-6.76 e-05$ \\
\hline & & $(0.00652)$ & $(0.00727)$ & $(0.00749)$ & $(0.000124)$ \\
\hline Industry Dummy & & & -1.295 & -1.295 & -0.0216 \\
\hline Year Dummy & & & -0.727 & -0.727 & -0.00426 \\
\hline \multirow[t]{2}{*}{ Constant } & $-1.058^{* * *}$ & $-24.27^{\star \star *}$ & $-27.30^{* * *}$ & $-27.30^{* * *}$ & $-0.108^{* * *}$ \\
\hline & $(0.249)$ & $(2.245)$ & (2.869) & (3.485) & $(0.0292)$ \\
\hline LR Chi-Sqrd. & $29.93^{* * *}$ & $429.00^{\star \star *}$ & $465.43^{* * *}$ & $155.45^{\star * *}$ & \\
\hline Pseudo R2 & 0.03 & 0.519 & 0.564 & 0.564 & \\
\hline F-Statistics & & & & & $7.80^{\star \star \star}$ \\
\hline R-squared & & & & & 0.230 \\
\hline Observations & 596 & 596 & 596 & 596 & 596 \\
\hline
\end{tabular}

Standard errors in parentheses ${ }^{* * *} p<0.01,{ }^{* *} p<0.05,{ }^{*} p<0.1$ Where LKPD is Likelihood to pay dividends, DVTS is dividends scaled by total assets, BDIVER is gender diversity, FINEXP is financial experts on board, FAGE is firm age, FSIZE is firm size, FLEV is firm LEVERAGE, rete is retained earnings to total capital, SLGRWT is sales growth, IND and FIRM is industry and firms dummies respectively. 
dividends. Hence, hypothesis one is supported. The finding is also in line with the argument for female directors on board based on the status characteristics theory. Thus, having a minority member on the board (Terjesen et al., 2009) will help protect shareholders, therefore, influencing the likelihood to pay dividends. This finding confirms the evidence that a female director positively influences the decision to pay dividends (Byoun et al., 2016; Pucheta-Martínez \& BelOms, 2016).

The results in Table 3 also show the association between financial experts serving on a board and the likelihood to pay dividends. In line with the predicted hypothesis, the logistics regression reveals a positive and statistically significant association between financial experts and likelihood to pay dividends. This means that the probability to pay dividends is higher with a greater percentage of financial experts serving on the board. The evidence also indicates financial experts tend to protect their reputations by strengthening and complementing the role of dividends as a control mechanism in the firm, hence, disgorging cash to the owners. The finding, therefore, lends support to the second hypothesis, that presence of financial experts on the board having the incentive (agency theory) as well as the ability (resource dependence theory) to monitor management will mitigate conflicts between shareholders and management. This result is in line with prior studies, which showed that a CEO with financial expertise is related to a higher likelihood of paying dividends (Custodio \& Metzger, 2014). Given the monitoring role of financial experts, the result is also consistent with the findings of Jeanjean and Stolowy (2009) that financial experts improve monitoring and the conclusion that financial expertise and monitoring tools mechanisms appear to strengthen each other. The result also in agreement with Kibiya et al. (2016) that financial experts improve monitoring and, therefore, enhance earnings quality. Consequently, Hypothesis two $\left(\mathrm{H}_{2}\right)$ is supported.

Results base on the size of a firm indicates a positive and significant association with the payout of dividends. This means larger firms have a higher likelihood to pay dividends than smaller firms in the capital market. This evidence supported the findings of Fama and French (2001) and Fatemi and Bildik (2012) that larger firms are more likely to pay dividends. Consistent with the previous evidence, the results presented in Table 3 also reveal a negative and statistically significant between leverage and likely to pay dividend indicating that debt is a constrain on paying dividends. Hence, high leveraged firms are less likely to pay dividends. The result is in agreement with previous evidence that shows a negative association between leverage and likelihood to pay dividends (Abdulkadir et al., 2016; Byoun et al., 2016). Furthermore, growth opportunity is also found to be positively and statistically significant with respect to the payment of dividends, thus, implying that high growth firms are those that are likely to pay dividends. The finding is in agreement with Abor and Fiador (2013) who reported positive association between dividends and growth. However, the evidence contradicts other previous findings that indicate the lower likelihood of growth firms to pay dividends (Abdulkadir et al., 2016; Fama \& French, 2001; Fatemi \& Bildik, 2012).

Consequently, the study also estimates a separate logistic regression using robust standard error model (4) in Table 3. The standard errors are clustered at the firm level because each firm will appear several times, and this appearance makes the observations to be not independent, which may affect the z-statistics. This will allow the study to correct for heteroscedasticity and serial correlation threats (Rogers, 1993). Interestingly, the result of the estimation remains intact and statistically significant. The results are reported in Table 3, column 5 .

The study also examines the relationship between the test independent variables and dividend payout. In line with Jiraporn, Kim, and Kim (2011) and Byoun, Chang, and Kim (2016) dividend payout is measured as cash dividends on ordinary shares scaled by total assets. The model estimation is shown in Table $\mathbf{3}$, column 6. This specification suggests that gender diversity and financial expertise on a board are positively related with dividend payout. Summarily, all the models consistently supported the prediction that gender and financial expertise have significant and positive effects on likelihood to pay dividends. Thus, the study concluded that gender diversity and financial expertise are important determinant of dividends policy.

\section{CONCLUSION}

This study offered a different perspective to the dividend payout likelihood model. The study provides an extension to the dividend likelihood model by incorporating, among others, two attributes of board of directors: gender diversity and financial expertise. The analyses revealed that a higher percentage of female directors and financial expertise on board results in a 
positive and significant effect on the likelihood of dividend payout. The results suggest that both female directors and financial expertise play a critical role in addressing agency conflicts, particularly in a weak environment such as Nigeria. The evidence also suggests that a female serving on the board will strive hard to discharge her responsibilities in part because she is perceived to be of low status compared with a male serving on the board. Thus, she is likely to protect the interests of shareholders by influencing the decision to pay dividends. Similarly, due to incentives combined with the ability to monitor, financial experts prefer to use dividends as a mechanism to control management from perquisite consumption of a firm's free cash flow.

The findings from this study have several implications for investors (existing or potential investors) and regulatory bodies. First, corporate attributes, but particularly diversity on the board, are important in considering the decision to pay dividends when other firm characteristics suggest that firm pays a dividend. In this regard, female and financial experts serving on the board will not hesitate to ratify on the decision that will lead to the payment of dividends. Second, female and financial experts consider that accumulating cash in a firm will enable the management to make inappropriate investments, thereby, exposing shareholders to greater agency problems. In other words, managers will embark on an investment that may be at expense of the shareholders. Third, this study should serve as a guide for investors who have a passion for dividends about which firms they should select for their investments. Because firms with female and financial experts serving on a board protect the interests of investors by distributing cash dividends when firm characteristics call for that decision. Fourth, shareholders should carefully monitor any changes on the board because having fewer divers of dividends on board in terms of female and financial experts may be detrimental to their investments.

Sequel to the findings, the study, therefore, recommends that regulatory authorities such as the Nigerian SEC and the Nigerian Stock Exchange should continue to encourage and offer incentives to firms that increase the percentage of board membership of female directors as well as those that have yet to recruit female directors into their board. This will complement their monitoring and supervising role in terms protecting the interests of the shareholders.
Further, because most firms tended to have a financial expert serving on the board, the study recommends that regulatory authorities should provide upper limits on the number of financial experts that a firm can have. This will enable the financial expert directors to function effectively in accordance with the terms of their contracts and, therefore, limit the possibility of free riding problems. That is because having excess financial experts on board is at the expense of other experts that a firm may require. Hence, a trade-off between the number of financial experts and other experts is important.

\section{REFERENCES}

Abdulkadir, R. I., Abdullah, N. A. H., \& Wong, W. C. (2016). Dividend payment behaviour and its determinants: The Nigerian evidence. African Development Review, 28(1), 53-63. https://doi.org/10.1111/1467-8268.12166

Abor, J., \& Fiador, V. (2013). Does corporate governance explain dividend policy in Sub-Saharan Africa? International Journal of Law and Management, 55(3), 201-225. https://doi.org/10.1108/17542431311327637

Adams, R. B., \& Ferreira, D. (2009). Women in the boardroom and their impact on governance and performance. Journal of Financial Economics, 94(2), 291-309. https://doi.org/10.1016/j.jfineco.2008.10.007

Adegbite, E. (2015). Good corporate governance in Nigeria: Antecedents, propositions and peculiarities. International Business Review, 24(2), 319-330. https://doi.org/10.1016/j.ibusrev.2014.08.004

Adegbite, E., Amaeshi, K., \& Amao, O. (2012). The politics of shareholder activism in Nigeria. Journal of Business Ethics, 105(3), 389-402. https://doi.org/10.1007/s10551-011-0974-y

Adewale, A. (2013). Corporate governance: A comparative study of the corporate governance codes of a developing economy with developed economies. Research Journal of Finance and Accounting, 4(1), 65-78.

Adeyemi, A. (2010). An evaluation of corporate governance practices in Nigeria: challenges and recommendations. Available at SSRN 1648623 https://doi.org/10.2139/ssrn.1648623

Agrawal, A., \& Chadha, S. (2005). Corporate Governance and Accounting Scandals *, XLVIII(October). https://doi.org/10.1086/430808

Ali, M., Ng, Y. L., \& Kulik, C. T. (2014). Board age and gender diversity: A test of competing linear and curvilinear predictions. Journal of Business Ethics, 125(3), 497-512. https://doi.org/10.1007/s10551-013-1930-9

Amidu, M., \& Abor, J. (2006). Determinants of dividend payout ratios in Ghana. The Journal of Risk Finance, 7(2), 136-145 https://doi.org/10.1108/15265940610648580

Arnegger, M., Hofmann, C., Pull, K., \& Vetter, K. (2013). Firm size and board diversity. Journal of Management and Governance, 1-27. https://doi.org/10.1007/s10997-013-9273-6

Baker, H. K., Dutta, S., \& Saadi, S. (2008). Impact of financial and multinational operations on manager perceptions of dividends. Global Finance Journal, 19(2), 171-186. https://doi.org/10.1016/j.gfj.2007.11.002

Benjamin, S. J., \& Zain, M. M. (2015). Corporate governance and dividends payout: are they substitutes or complementary? Journal of Asia Business Studies, 9(2), 177-194. https://doi.org/10.1108/JABS-08-2014-0062 
Brown, P., Beekes, W., \& Verhoeven, P. (2011). Corporate governance, accounting and finance: A review. Accounting and Finance, 51(1), 96-172. https://doi.org/10.1111/j.1467-629X.2010.00385.x

Byoun, S., Chang, K., \& Kim, Y. S. (2016). Does corporate board diversity affect corporate payout policy? Asia-Pacific Journal of Financial Studies, 45(1), 48-101. https://doi.org/10.1111/ajfs.12119

Carter, D. a., D'Souza, F., Simkins, B. J., \& Simpson, W. G. (2010). The gender and ethnic diversity of US boards and board committees and firm financial performance. Corporate Governance, 18(5), 396-414. https://doi.org/10.1111/j.1467-8683.2010.00809.x

Cock, A. C. (2014). A gentle introduction to Stata (4th ed.). Texas, USA: Stata Press.

Cunningham, L. A. (2008). Rediscovering board expertise: legal implications of the empirical literature. U. Cin. L. Rev, 465. https://doi.org/10.2139/ssrn.1024261

Custodio, C., \& Metzger, D. (2014). Financial expert CEOs: CEO's work experience and firm's financial policies. Journal of Financial Economics, 114(1), 125-154. https://doi.org/10.1016/j.jfineco.2014.06.002

DeAngelo, H., DeAngelo, L., \& Stulz, R. M. (2006). Dividend policy and the earned/contributed capital mix: a test of the life-cycle theory. Journal of Financial Economics, 81(2), 227-254. https://doi.org/10.1016/j.jfineco.2005.07.005

Defond, M. L., Hann, R. N., Xuesong, H. U., \& Engel, E. (2005). Does the market value financial expertise on audit committees of boards of directors? Journal of Accounting Research, 43(2), 153-204. https://doi.org/10.1111/j.1475-679x.2005.00166.x

Fama, E. F., \& French, K. R. (2001). Disappearing dividends: Changing firm characteristics or lower propensity to pay? Journal of Financial Economics, 60(1), 3-43. https://doi.org/10.1016/S0304-405X(01)00038-1

Fatemi, A., \& Bildik, R. (2012). Yes, dividends are disappearing: Worldwide evidence. Journal of Banking and Finance, 36(3), 662-677. https://doi.org/10.1016/j.jbankfin.2011.10.008

Ferris, S. P., Sen, N., \& Yui, H. P. (2006). God save the queen and her dividends: corporate payouts in the United Kingdom. The Journal of Business, 79(3), 1149-1173. https://doi.org/10.1086/500672

Florackis, C., Kanas, A., \& Kostakis, A. (2015). Dividend policy, managerial ownership and debt financing: A non-parametric perspective. European Journal of Operational Research, 241(3), 783-795. https://doi.org/10.1016/j.ejor.2014.08.031

Gujarati, D. N. (2004). Basic econometrics. McGraw-Hill international (Economic s). New York: McGraw-Hill international. https://doi.org/10.2307/2344828

Güner, B. A., Malmendier, U., \& Tate, G. (2008). Financial expertise of directors. Journal of Financial Economics, 88(2), 323-354. https://doi.org/10.1016/j.jfineco.2007.05.009

Hillman, A. J., \& Dalziel, T. (2003). Boards of directors and firmperformance: integrating agency and resource dependence perspectives. Academy of Management Review, 28(3), 383396. https://doi.org/10.2307/30040728

Hu, A., \& Kumar, P. (2004). Managerial entrenchment and payout policy. Journal of Financial and Quantitative Analysis, 39(4), 759. https://doi.org/10.1017/S0022109000003203

Ittonen, K., Miettinen, J., \& Vähämaa, S. (2010). Does female representation on audit committees affect audit fees. Quarterly Journal of Finance and Accounting, 49(3), 113139.
Jeanjean, T., \& Stolowy, H. (2009). Determinants of board members' financial expertise: Empirical evidence from France. International Journal of Accounting. https://doi.org/10.1016/j.intacc.2009.09.002

Jensen, M. C. (1993). The modern industrial revolution, exit, and the failure of internal control systems. Journal of Finance, 48(3), 831-880. https://doi.org/10.1111/j.1540-6261.1993.tb04022.x

Jensen, M. C., \& Meckling, W. H. (1976). Theory of the firm: Managerial behavior, agency costs and ownership structure. Journal of Financial Economics, 3(4), 305-360. https://doi.org/10.1016/0304-405X(76)90026-X

Jiraporn, P., Kim, J. C., \& Kim, Y. S. (2011). Dividend payouts and corporate governance quality: An empirical investigation. Financial Review, 46(2), 251-279. https://doi.org/10.1111/j.1540-6288.2011.00299.x

Kastlunger, B., Dressler, S. G., Kirchler, E., Mittone, L., \& Voracek, M. (2010). Sex differences in tax compliance: Differentiating between demographic sex, gender-role orientation, and prenatal masculinization (2D:4D). Journal of Economic Psychology, 31(4), 542-552. https://doi.org/10.1016/j.joep.2010.03.015

Kibiya, U. M., Che-Ahmad, A., \& Amran, N. A. (2016). Audit committee independence, financial expertise, share ownership and financial reporting quality: Further evidence from Nigeria. International Journal of Economics and Financial Issues, 6(7), 125-131.

Knyazeva, A., Knyazeva, D., \& Masulis, R. W. (2013). The supply of corporate directors and board independence. Review of Financial Studies, 26(6), 1561-1605. https://doi.org/10.1093/rfs/hht020

La Porta, R., Lopez-de-Silanes, F., Shleifer, A., \& Vishny, R. (2000). Investor protection and corporate governance. Journal of Financial Economics, 58(1-2), 3-27. https://doi.org/10.1016/S0304-405X(00)00065-9

La Porta, R., Lopez-De-Silanes, F., Shleifer, A., \& Vishny, R. W. (2000). Agency problems and dividend policies around the world. The Journal of Finance, 55(1), 1-33. https://doi.org/10.1111/0022-1082.00199

Larkin, M. B., Bernardi, R. A., \& Bosco, S. M. (2013). Does female representation on boards of directors associate with increased transparency and ethical behavior? Accounting and the Public Interest, 13(1), 132-150. https://doi.org/10.2308/apin-10374

Man, C., Kong, H., \& Wong, B. (2013). Corporate governance and earnings management: A survey of literature. The Journal of Applied Business Research, 29(2), 391-418. https://doi.org/10.19030/jabr.v29i2.7646

Mishra, R. K., \& Jhunjhunwala, S. (2013). Diversity and the effective corporate board. Diversity and the Effective Corporate Board. https://doi.org/10.1016/B978-0-12-410497-6.00002-0

Mordi, C., \& Obanya, S. (2014). Gender diversity on boards of publicly quoted companies in Nigeria. Nigerian Observatory on Corporate Governance, 5(1).

Nwidobie, B. M. (2011). Dividend payouts and shareholders' satisfaction in quoted firms in Nigeria. European Journal of Social Sciences, 22(4), 541.

Officer, M. S. (2006). Dividend policy, dividend initiations, and governance (Unpublished working paper). Unpublished working paper, University of Southern California.

Ofo, N. (2011). Securities and Exchange Commission of Nigeria's draft revised code of corporate governance: An appraisal. Journal of African Law, 55(2), 280-299. https://doi.org/10.1017/S0021855311000143

Ooi, C.-A., Hooy, C.-W., \& Mat Som, A. P. (2015). Diversity in human and social capital: Empirical evidence from Asian tourism firms in corporate board composition. Tourism Management, 48, 139-153.

https://doi.org/10.1016/j.tourman.2014.11.002 
Pucheta-Martínez, M. C., \& Bel-Oms, I. (2016). The board of directors and dividend policy: the effect of gender diversity. Industrial and Corporate Change, 25(3), 1-25. https://doi.org/10.1093/icc/dtv040

Rogers, W. H. (1993). Regression standard errors in clustered samples. Stata Technical Bulletin, 13, 19-23.

Setia-Atmaja, L. Y. (2009). Governance mechanisms and firm value: the impact of ownership concentration and dividends. Corporate Governance, 17(6), 694-709. https://doi.org/10.1111/j.1467-8683.2009.00768.x

Sharma, V. (2011). Independent directors and the propensity to pay dividends. Journal of Corporate Finance, 17(4), 1001-1015. https://doi.org/10.1016/j.jcorpfin.2011.05.003
Tangjitprom, N. (2013). Propensity to pay dividends and catering incentives in Thailand. Studies in Economics and Finance, $30(1), 45-55$. https://doi.org/10.1108/10867371311300973

Tarling, R. (2009). Statistical modelling for social researchers principles and practice. Routledge, London. https://doi.org/10.4324/9780203929483

Terjesen, S., Sealy, R., \& Singh, V. (2009). Women directors on corporate boards: A review and research agenda. Corporate Governance, 17(3), 320-337. https://doi.org/10.1111/j.1467-8683.2009.00742.x

The World Bank. (2017). Doing business measuring business regulations: Economy rankings. Retrieved October 20, 2017, from http://www.doingbusiness.org/rankings

Received on 18-07-2019

Accepted on 01-08-2019

Published on 24-09-2019

DOI: https://doi.org/10.6000/1929-7092.2019.08.60

(C) 2019 Adamu et al.; Licensee Lifescience Global.

This is an open access article licensed under the terms of the Creative Commons Attribution Non-Commercial License (http://creativecommons.org/licenses/by-nc/3.0/) which permits unrestricted, non-commercial use, distribution and reproduction in any medium, provided the work is properly cited. 